Scientific Note

\title{
Sighting of Pontia daplidice moorei (Röber) (Lepidoptera: Pieridae: Pierinae) from Meghalaya, Northeastern India: a new locality record
}

Avistamiento de Pontia daplidice moorei (Röber) (Lepidoptera: Pieridae: Pierinae) en Meghalaya, noreste de la India: un nuevo registro de localidad

Atanu Bora ${ }^{1}$, Laishram Ricky Meitei $^{2}$, Sachin Sharma ${ }^{3}$, Suman Bhowmik ${ }^{4}$ and Ngangom Aomoa ${ }^{5}$

${ }^{1}$ Department of Zoology, Moran College, Assam, 785670, India. 鼻atanubora2019@gmail.com

Botanical Survey of India, Eastern Regional Centre, Shillong, 793003, Meghalaya, India.E-mail:Irmeitei2019@ gmail.com

${ }^{3}$ Botanical Survey of India, Northern Regional Centre, Dehradun, 248195, Uttarakhand, India. E-mail: sachinbsi2012@yahoo.co.in

${ }^{4}$ Lepidoptera Conservation and Research Division, Wild Tripura Foundation, Agartala, Tripura, 799007, India. E-mail: sumanbhowmikwildlife@gmail.com

${ }^{5}$ Department of Physics, Assam Don Bosco University, Assam, 782402, India. E-mail: aomoa13@gmail.com

\section{ZooBank: urn:lsid:zoobank.org:pub: 02259FFD-2910-4E93-B68B-6DE5F57A5170 \\ https: / / doi.org/10.35249/ rche.46.3.20.10}

\begin{abstract}
The farmland visitor Bath White, Pontia daplidice moorei is recorded for the first time in Meghalaya. The butterfly is documented in an opportunistic survey on 17.v.2015 along the GuwahatiShillong road, near Shangbangla village at an elevation of 520 meters. This record will help in updating the status of butterfly fauna in Meghalaya, India.
\end{abstract}

Key words: Bath white, Pontia daplidice moorei, first record, North-east.

Resumen. El visitante de las tierras de cultivo, Pontia daplidice moorei, se registra por primera vez en Meghalaya. La mariposa fue observada el 17 de mayo de 2015 a lo largo de la carretera GuwahatiShillong, cerca del pueblo de Shangbangla a una altitud de 520 metros. Este registro ayudará a actualizar el estado de la fauna de mariposas de Meghalaya, India.

Palabras clave: Bath White, Pontia daplidice moorei, primer registro, noroeste.

The genus Pontia Fabricius, 1807 accounts for 5 species and 3 subspecies in India (Varshney \& Smetacek 2015). Among them Pontia daplidice (Linnaeus, 1758) Bath White has a wide distribution range from western Europe, northern Africa, eastward through west Asia, the western Himalaya in Pakistan and India, the central Himalaya in Nepal and south west China (Kehimkar 2016). In literature, the subspecies Pontia daplidice moorei (Röber, 1907) is found to have a distribution of western Himalaya in Pakistan and India, North-east in the eastern Himalaya, the central Himalaya in Nepal as well as in northern Thailand, Laos and Yunnan (Inayoshi 2012; Varshney \& Smetacek 2015).

In recent literature, Pontia daplidice has distribution range from Jammu and Kashmir to Uttarakhand in India (Kehimkar 2008; Singh 2010) until recently Kehimkar (2016) updated its distribution range to Arunachal Pradesh, owing to the record of Naro \& Sondhi (2013) who recorded it from Nagaland and Arunachal Pradesh. The butterfly has also been

Received 29 July 2020 / Accepted 10 August 2020 / Published online 28 August 2020

Responsible Editor: José Mondaca E. 
reported from Assam and Manipur in North-east India (Singh \& Gogoi 2013). Additional records of this species from Sikkim, West Bengal and Nepal can be presently found in butterflies of India website (http: / / www.ifoundbutterflies.org/sp/ 782 / Pontia-daplidice).

Bingham (1907) and Evans (1932) reported its distribution as Baluchistan (in Afghanistan), east to Chitral (in Pakistan) and Murree (in Kashmir). After these two authors, Talbot (1939) mentioned its distribution as north western Himalaya. Wynter-Blyth (1957) reports its distribution in Baluchistan, Chitral and Peshawar (both in Pakistan), Kashmir, east to Shipki (in Himachal Pradesh). It is also reported from Bhutan (van der Poel \& Wangchuk 2007). Inayoshi (2012) reports the distribution of the subspecies in northwest Himalayas, Laos, Tibet, Northern Thailand and Yunnan.

Sighting of Pontia daplidice moorei in Shangbangla village. Shangbangla $\left(25^{\circ} 57^{\prime} 5.76^{\prime \prime}\right.$ $\mathrm{N}, 91^{\circ} 51^{\prime} 53.64^{\prime \prime} \mathrm{E}$ ) is a small village situated in Umling panchayat in Ri-bhoi district, Meghalaya. The village is located at an elevation of approximately 540 meters and is a part of the National Highway 40 connecting Assam with Meghalaya, popularly known as GS road. Agriculture is the main source of living of this village and one can easily observe large tracts of agricultural plots on both sides of the highway while travelling from Assam to Meghalaya. The highway has a rich diversity of nectaring plants such as Chromolaena odorata (L.) R.M. King \& H. Rob., Ageratum conyzoides L., Lantana camara L., Aesculus assamica Griff., etc. that often attracts butterflies and other insects.

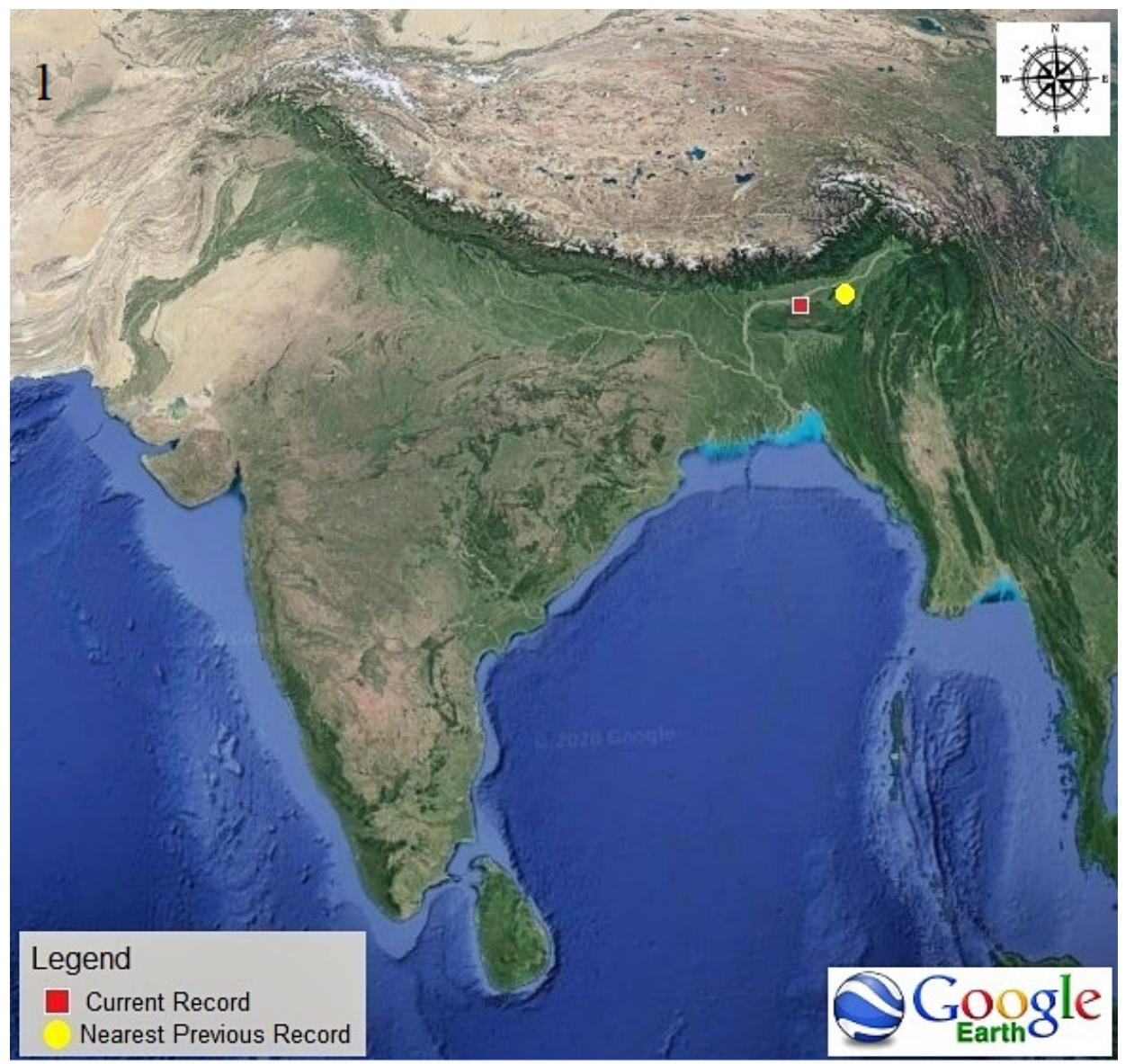

Figure 1. Map showing the new locality of Pontia daplidice moorei (Röber, 1907) in Shangbangla village, Meghalaya, India. 
The observation on this paper is a part of the butterfly inventory and monitoring program of North-east India, the authors are involved in for the last five years (Bora \& Meitei 2014a, 2014b; Bora et al. 2014, 2019; Bhowmik et al. 2020). On 17.v.2015, we were in a butterfly trip to Meghalaya travelling over the GS road on the National Highway 40. We stopped for a tea break in a stall in the middle of our journey near Shangbangla village. We were observing butterflies in the nearby habitats while enjoying our tea break. At about 07:18 hr (255' $14.76^{\prime \prime} \mathrm{N}, 9^{\circ} 51^{\prime} 52.92^{\prime \prime}$ E), the authors, Sachin Sharma and Atanu Bora spotted a Pontia hovering around the nectaring plant, Ageratum conyzoides along roadsides. They rushed to their cameras and took few photographs of the butterfly when it finally perched in a nearby bush. It exactly matched the original description of Pontia daplidice and photographs illustrated in various literatures (Evans 1932; Wynter-Blyth 1957). The white butterfly with green blotches on the underside of hindwings proved the identity of the species as Pontia daplidice, Bath White.

The adult male is white on the upperside having black apex with white spots and lines on the forewing; presence of a broad-black patch at end-cell; underside hindwing with green blotches. Female similar to male, but with a discal spot on upper forewing and two obscure rows of marginal spots on upper hindwing.

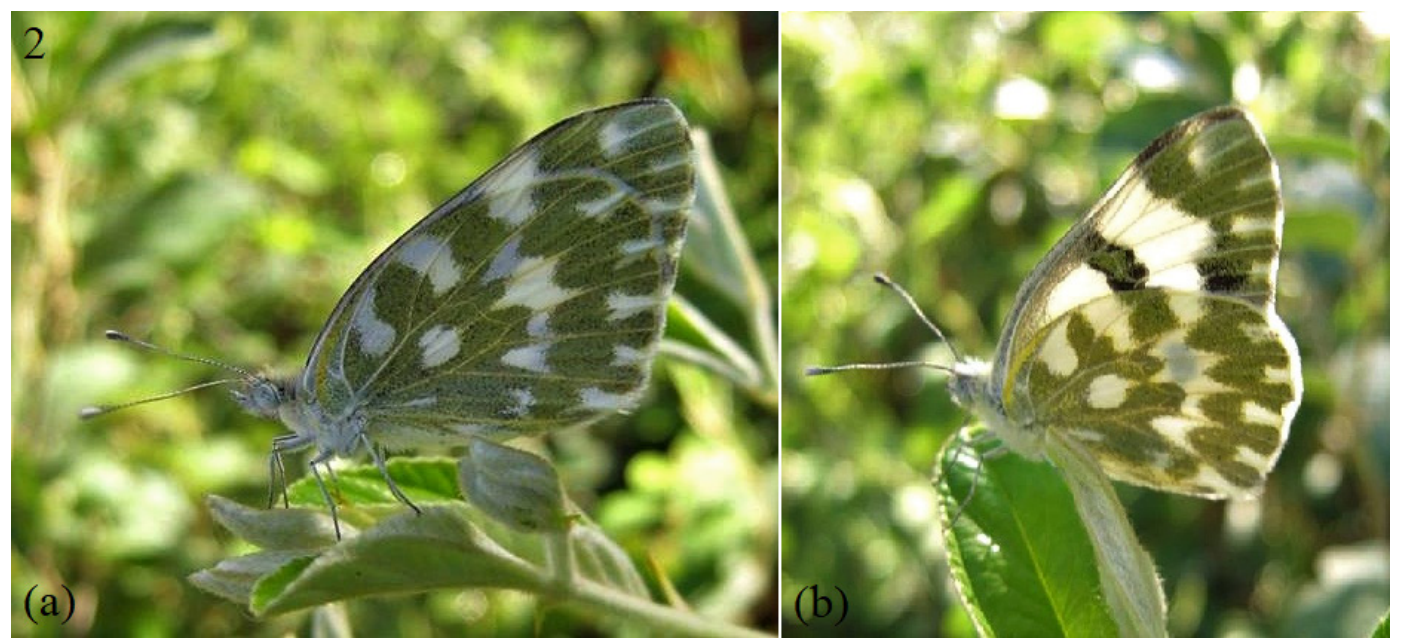

Figure 2. (a) and (b). Photographic records of Pontia daplidice moorei in Shangbangla village, Meghalaya, India.

Significance of the sighting. The major historic and taxonomic work on butterflies in Meghalaya was done in Khasi and Jaintia hills in eastern Meghalaya (Butler 1879; Swinhoe 1893, 1896; Parsons \& Cantlie 1948; Cantlie 1952, 1956; Radhakrishnan et al. 1989) and recently in Garo Hills (Kunte et al. 2012; Sondhi et al. 2013). In addition, more publications about faunal and butterfly diversity of the state have come out in the recent times (Alfred 1999; Hatter et al. 2004; Bora et al. 2014). However, none of these studies record Pontia daplidice moorei from the state. The present observation therefore provides a new locality record in its distribution in India and also able to justify the first record of this species in Meghalaya, extending its known range by a distance of $200 \mathrm{~km}$ from the nearest previous record.

This new locality record is important in the context of updating the distribution range of this species in India. Multiple records of this species from different states in North-east India clearly indicate that the subspecies might have been overlooked in the past historic works. The butterfly must have been constantly colonising new areas of the country being a farmland visitor. The larvae of the Indian subspecies Pontia daplidice moorei were reared by Sharma (2005) successfully on Lepidium ruderale Linnaeus (Brassicaceae). Additional records in future surveys will definitely help to map the distribution of this species and subspecies in the Indian subcontinent. 


\section{Literature Cited}

Alfred, J.R.B. (1999) Fauna of Meghalaya-Part 6. Insecta (Diptera and Lepidoptera). I-IV, 1-537 pp. (Publishcd-Director, ZSI, Calcutta).

Bhowmik, S., Malakar, S. and Bora, A. (2020) Rediscovery of Ypthima watsoni Moore, 1893 (Lepidoptera: Nymphalidae: Satyrinae) to India and new record to Tripura, North East, India. Journal of Entomology and Zoology Studies, 8(3): 2037-2040.

Bingham, C.T. (1907) The Fauna of British India including Ceylon and Burma. ButterfliesVolume II. Taylor and Francis Ltd., London.

Bora, A. and Meitei, L.R. (2014a) Butterfly fauna (Order: Lepidoptera) in five major tea gardens of Sivasagar District, Assam, India. Biological Forum - An International Journal, 6(2): 7-15.

Bora, A. and Meitei, L.R. (2014b) Diversity of butterflies (Order: Lepidoptera) in Assam University campus and its vicinity, Cachar District, Assam, India. Journal of Biodiversity and Environmental Sciences, 5(3): 328-339.

Bora, A., Meitei, L.R. and Deb, M. (2014) Butterfly species richness and diversity in experimental botanic garden, botanical survey of India, ERC, Umiam, Meghalaya, India. Journal of Entomology and Zoology Studies, 2(5): 108-113.

Bora, A., Meitei, L.R. and Sharma, S. (2019) Mapping butterfly hotspots: A new approach to identify prime butterfly areas of Meghalaya, India. International Journal of Emerging Technologies, 10(2): 440-445.

Butler, A.G. (1879) On a collection of Lepidoptera from Cachar. Transactions of the Entomological Society of London, 1879: 1-8.

Cantlie, K. (1952) More butterflies of the Khasi and Jaintia Hills, Assam. Journal of the Bombay Natural History Society, 51: 42-60.

Cantlie, K. (1956) Hesperiidae of Khasi and Jaintea Hills. Journal of the Bombay Natural History Society, 54: 212-215.

Churi, P., Mazumder, S. and Soman, A. (2020) Pontia daplidice (Linnaeus, 1758) - Bath White. Kunte, K., Sondhi, S. and Roy, P. (Chief Editors). Butterflies of India, v. 2.90. Indian Foundation for Butterflies)

Evans, W.H. (1932) The Identification of Indian butterflies-2nd Edition. Bombay Natural History Society, Mumbai, 454 pp.

Hatter, S.J.S., Sen, N., Rosamma, M. and Sharma, S. (2004) Faunal Diversity of Saipung Wild Life Sanctuary, Narpuh Reserve Forest, Jaintia Hills, Meghalaya, Conservation Area Series, 21: 1-66. (Published by the Director, Zool. Surv. India, Kolkata).

Inayoshi, Y. (2012) A checklist of butterflies in Indo-China chiefly from Thailand, Laos and Vietnam. (http:/ / yutaka.it-n.jp/ pie/20400010.html) (Retrieved on 31 ${ }^{\text {st }}$ December 2012).

Kehimkar, I. (2008) The Book of Indian Butterflies. Bombay Natural History Society and Oxford University Press, Oxford, xvi+497pp.

Kehimkar, I. (2016) Butterflies of India. Bombay Natural History Society, Mumbai. Pp xii + 528.

Kunte, K., Sondhi, S., Sangma, B., Lovalekar, R., Tokekar, K. and Agavekar, G. (2012) Butterflies of the Garo Hills of Meghalaya, northeastern India: their diversity and conservation. Journal of Threatened Taxa, 4(10): 2933-2992.

Naro, T. and Sondhi, S. (2013) Sightings of Bath White Pontia daplidice moorei Röber, 1907 (Lepidoptera: Pieridae: Pierinae: Pierini) from Arunachal Pradesh and Nagaland, India. Journal of Threatened Taxa, 5(7): 4122-4124.

Parsons, R.E. and Cantlie, K. (1948) The butterflies of the Khasia and Jaintia hills, Assam. Journal of the Bombay Natural History Society, 47: 498-522.

Radhakrishnan, C., Alfred, J.RB. and Rynth, M.R. (1989) Butterflies of Shillong and Its Environs. Science \& Technology Cell, Govt of Meghalaya, Shillong, 70 pp.

Sharma, N. (2005) Life history of Pontia daplidice moorei (Rober) (Lepidoptera: Pieridae) from Himachal Pradesh, India. Journal of the Lepidopterists's Society, 59(3): 170-171. 
Singh, I.J. and Gogoi, M.J. (2013) A new range record for the Bath White butterfly Pontia daplidice for North-east India. Bionotes, 15(2): 59-60.

Singh, A.P. (2010) Butterflies of India. Om Books International, 183 pp.

Sondhi, S., Kunte, K., Agavekar, G., Lovalekar, R. and Tokekar, K. (2013) Butterflies of the Garo Hills. Samrakshan Trust (New Delhi), Titli Trust (Dehradun) and Indian Foundation for Butterflies (Bengaluru). xvi+200 pp.

Swinhoe, C. (1893) A list of the Lepidoptera of the Khasia Hills. Part I. Transactions of the Entomological Society of London, 1893(41): 267-330.

Swinhoe, C. (1896) New species of Lepidoptera from Khasia Hills. Annals and Magazine of Natural History, including Zoology, Botany, and Geology, 17(6): 357-363.

Talbot, G. (1939) The Fauna of British India including Ceylon and Burma. Butterflies. Vol. I. Taylor and Francis Ltd., London, 600 pp.

van der Poel, P. and Wangchuk, T. (2007) Butterflies of Bhutan - Mountains, hills and valleys between 800 and $3000 \mathrm{~m}$. Royal Society for Protection of Nature (RSPN). Thimphu, Bhutan.

Varshney, R.K. and Smetacek, P. (2015) A Synoptic Catalogue of the Butterflies of India. Butterfly Research Centre, Bhimtal and Indinov Publishing, New Delhi, ii + pp. 261, 8 pl.

Wynter-Blyth, M.A. (1957) Butterflies of the Indian Region. Bombay Natural History Society, Mumbai, 523 pp. 